\title{
Application of Rough TOPSIS Technique for the Analysis of Engineering System Failure Causes \\ Emovon I. ${ }^{*}$, Nwaoha T. C.
}

Federal University of Petroleum Resources, P.M.B. 1221, Effurun, Delta State, Nigeria

\author{
Article info: \\ Paper received: \\ The final version of the paper received: \\ Paper accepted online:
}

May 28, 2018

June 28,2018

June 30, 2018
"Corresponding Author's Address: emovon.ikuobase@fupre.edu.ng

\begin{abstract}
The prioritization of the causes of engineering system failure posed to be a challenge. Therefore, there is a need to develop a tool that will be used to identify critical problems of an engineering system to facilitate decision making in allocation of available resources in ensuring optimal system performance. In this paper, a rough technique for order preference by similarity to the ideal solution (Rough-TOPSIS) is proposed, which combines rough set theory and TOPSIS for the prioritization exercise in uncertain engineering environment. The technique is exemplified with a numerical example and advanced using information from experts. From the result of the analysis, factors/causes hampering the optimal performance of the engineering system have been revealed in order of importance. The proposed approach have comparative advantages over other hybrid methods as it can easily be implemented with hand calculation/spreadsheet, without requiring additional tools to evaluate decision criteria weights and aggregate experts opinions.
\end{abstract}

Keywords: rough set theory, Rough TOPSIS, engineering system, failure causes, decision criteria.

\section{Introduction}

Many developing countries are characterized with ineffective water transportation system, poor telecommunication system, poor health care delivery system, ineffective rail way system and ineffective power generation system. These have hampered their economic and social growth. The engineering systems failures have been attributed to ineffective maintenance, misappropriation of fund among other reasons. The level of impact of the different failure causes on engineering system varies. The analysis of the various failure causes in the order of importance is therefore imperative.

However, in the literature, most of the authors have been mainly worried with the bane of power generation with specific reference to Nigeria. Ohajianya et al. [1] in their studies, identified factors such as inept manpower and deficient power reform as the causes of epileptic electricity supply in Nigeria. Olaoye et al. [2] in a similar research work, examined the bases of power crisis in Nigeria and recommended the use of renewable energy as means of reducing and / or eliminating the crisis. Sambo et al. [3] identified elements such as deficiency of fund and low involvement of private sector, as the reason for energy predicament in their paper. The above papers only identified the causes of engineering system failure, without prioritizing them in order of importance.

Only limited papers are found in existing literature with respect to prioritization of the causes of engineering system failure but specifically for power generation system problems. Emovon and Nwaoha [4] utilised an integrated AHP and MOORA method for ordering the problems of power generation in Nigeria. Emovon and Samuel [5] applied a combination of entropy and MultiAttribute utility Theory (MAUT) methods in the ranking of alternative solutions to power generation problems.

Nevertheless, the methods utilized by the above authors have shortcomings, which are addressed in the approach suggested in this paper, for the prioritization of engineering system failure causes. The method proposed is the Rough TOPSIS technique, which is an integration of the Rough Set Theory and the TOPSIS method. Furthermore, the analysis in this paper is not limited to power generation system but addresses majority of engineering system.

The causes of engineering system failure in most developing countries are numerous and the resultant effects are poor sea transport delivery, low power generation, 
poor telecommunication and poor health care service delivery. Some common causes of the system failure are ineffective maintenance, misappropriation of fund, insufficient fund, insufficient skilled manpower and wrong industrial setting location and are described as follows:

1. Ineffective maintenance (AT1): the engineering system is poorly safeguarded and in most scenarios, the system is allowed to fail before being fixed. This approach has resulted to collapse of engineering system.

2. Misappropriation of fund (AT2): the meagre fund available for engineering system maintenance and expansion are misappropriated by bodies entrusted with the management of the systems.

3. Insufficient funding (AT3): the fund available for sustainability of the engineering system in most cases is grossly insufficient.

4. Insufficient skilled manpower (AT4): the skilled manpower needed for effective operation and maintenance of engineering system are lacking or inadequate.

5. Wrong location (AT5): the engineering systems are in most scenarios sited in wrong location, and this is generally due to nepotism and ethnicity. The locations are normally far away from energy sources and skilled manpower which do result to industries incurring extra cost in terms of moving materials and human resources to system sites.

The above factors were carefully selected from the nine factors, Emovon and Nwaoha [4] identified as the problems of power generation in Nigeria. The five factors were selected and modified because they affect all engineering system.

The different engineering system failure causes are ranked in this paper with reference to some decision criteria. The decision criteria are listed and described as follows:

1. Damages (DC1): the failure of engineering system can damage firm image, cause personnel death or injuries and product or services delay. The different failure causes have vary degree of damaging effect and the one with the greatest effect is generally the most critical.

2. Environmental degradation (DC2): the failure of engineering system can produce reversible and irreversible damages to the environment. The engineering system failure cause with greater negative effect on the environment is considered most critical.

3. Engineering system efficiency (DC3): the failure cause that will impact more negatively on the system service delivery is considered as most critical failure cause. The decision criteria are the modified version of Emovon and Nwaoha [4] to make them applicable to all engineering system rather than limiting it to power generation.

\section{Research Methodology}

\subsection{Rough set theory}

The approach commonly applied in overcoming vagueness of human mind which generally have negative impact on group decision making is the Rough Set Theory (RST) [6]. The approach was introduced by Pawlak [7]. RST resolve the challenges of uncertainty in group decision making, by applying lower and upper approximation [8].

Supposing $U$ is the universe, comprising all elements and $Y$ a random elements of $U . R$ is defined as a set of classes organized as $D_{1}<D_{2} \ldots<D_{n}$ [6]. The lower approximation, $\underline{A P M}\left(D_{i}\right)$ upper approximation, $\overline{A P M}\left(D_{i}\right)$ and boundary region, are thereforeexpressed as [9]:

$$
\begin{gathered}
\frac{\operatorname{APM}\left(D_{i}\right)}{A}=U\left\{Y \in \frac{U}{R(Y)} \leq D_{i}\right\} \\
\overline{A P M\left(D_{i}\right)}=U\left\{Y \in \frac{U}{R(Y)} \geq D_{i}\right\} \\
B D\left(D_{i}\right)=U\left\{Y \in \frac{U}{R(Y)} \neq D_{i}\right\}= \\
=\left\{Y \in \frac{U}{R(Y)}>D_{i}\right\} \cup\left\{Y \in \frac{U}{R(Y)}<D_{i}\right\}
\end{gathered}
$$

$D_{i}$ can be denoted in the form of Rough number, $R N\left(D_{i}\right)$, with the lower limit and upper limit expressed as equations 4 and 5 respectively [10]

$$
\begin{aligned}
& \underline{\operatorname{Lim}\left(D_{i}\right)}=\frac{\mathbf{1}}{P_{L}} \sum \frac{R(Y)}{(Y)} \in \underline{\operatorname{APM}\left(D_{i}\right)} \\
& \overline{\operatorname{Lim}\left(D_{i}\right)}=\frac{\mathbf{1}}{P_{U}} \sum \frac{R(Y)}{(Y)} \in \overline{\operatorname{APM}\left(D_{i}\right)}
\end{aligned}
$$

The difference between the upper limit and the lower limit of $R N\left(D_{i}\right)$, is $B D\left(D_{i}\right)$ expressed as

$$
B D\left(D_{i}\right)=\left[\operatorname{Lim}\left(D_{i}\right)-\underline{\operatorname{Lim}}\left(D_{i}\right)\right]
$$

where $P_{L}$ and $P_{U}$ denote number of elements in $\underline{A P M}\left(D_{i}\right)$ and $\overline{A P M}\left(D_{i}\right)$ respectively.

The interval arithmetic operation such as addition and division is also applicable to rough numbers, the operation can be found in the work of [10].

\subsection{Rough TOPSIS}

The Rough TOPSIS is a hybrid approach for analyzing group decision problem which combines Rough Set Theory with TOPSIS method. The RST is applied in operating vague data from experts involves in the group decision making process. The analyzed data then serve as input information into the TOPSIS method for final ranking of alternatives.

The analysis steps in the Rough TOPSIS are expressed as follows [9]:

Step 1. Decision matrix $X$, formation, having m number of alternatives $A T_{i}(i=1,2, \ldots, m)$ and n number of decision criteria, $D C_{j}(j=1,2, \ldots, n) . Z$ representing number of experts that partakes in the prioritization process. The decision matrix produced is indicated as: 


$$
X=\left[\begin{array}{ccccc}
x_{11}^{r} & x_{12}^{r} & x_{13}^{r} & \ldots & x_{1 n}^{r} \\
x_{21}^{r} & x_{2 \mathbf{2}}^{r} & x_{23}^{r} & \ldots & x_{2 n}^{r} \\
x_{3 \mathbf{1}}^{r} & x_{3 \mathbf{2}}^{r} & x_{33}^{r} & \ldots & x_{3 n}^{r} \\
\vdots & \vdots & \vdots & \ddots & \vdots \\
x_{m \mathbf{1}}^{r} & x_{m \mathbf{2}}^{r} & x_{m \mathbf{3}}^{r} & \ldots & x_{m n}^{r}
\end{array}\right]
$$

where $r=1,2, \ldots, z$, and $x_{i j}{ }^{r}(i=1,2, \ldots, m)$ denote rating of $r$-th expert for $i$-th alternative with respect to criterion $j$.

Step 2. The decision matrix is transformed into rough decision matrix $S$ using the equations (1) - (6), and the details of the transformation process can be found in the work of [10]:

$$
S=\left[\begin{array}{cccc}
{\left[x_{1 \mathbf{1}}^{L}, x_{1 \mathbf{1}}^{U}\right]} & {\left[x_{1 \mathbf{2}}^{L}, x_{1 \mathbf{2}}^{U}\right]} & \ldots & {\left[x_{1 m}^{L}, x_{1 m}^{U}\right]} \\
{\left[x_{2 \mathbf{1}}^{L}, x_{21}^{U}\right]} & {\left[x_{2 \mathbf{2}}^{L}, x_{2 \mathbf{2}}^{U}\right]} & \ldots & {\left[x_{\mathbf{2}}^{L}, x_{\mathbf{2}}^{U}\right]} \\
\vdots & \vdots & \ddots & \vdots \\
{\left[x_{n \mathbf{1}}^{L}, x_{n \mathbf{1}}^{U}\right]} & {\left[x_{n \mathbf{2}}^{L}, x_{n \mathbf{2}}^{U}\right]} & \ldots & {\left[x_{n m}^{L}, x_{n m}^{U}\right]}
\end{array}\right]
$$

where $x_{i j}{ }^{L}$ and $x_{i j}{ }^{U}$ indicate lower and upper limits of rough number

Step 3. Evaluation of standardized decision matrix with regard to rough number as follows:

$$
\begin{aligned}
& N x_{i j}^{L}=\frac{x_{i j}^{L}}{\left(\max _{i}\left[x_{i j}^{L} ; x_{i j}^{U}\right]\right)} \\
& N x_{i j}^{L}=\frac{x_{i j}^{L}}{\left(\max _{i}\left[x_{i j}^{L} ; x_{i j}^{U}\right]\right)}
\end{aligned}
$$

where $N x_{i j}{ }^{L}$ and $N x_{i j}{ }^{U}$ denote the upper and lower limits of the standardized rough matrix.

Step 4. Determination of the weighted standardized rough matrix expressed as:

$$
\begin{aligned}
Y_{i j}^{L} & =W_{i j}^{L} \cdot N x_{i j}^{L} \\
Y_{i j}^{U} & =W_{i j}^{U} \cdot N x_{i j}^{U}
\end{aligned}
$$

The rough weights of decision criteria; $W_{i j}{ }^{L}$ and $W_{i j}{ }^{U}$ analytical steps based on the equations (1) - (6) can be found in [9].

Step 5. Definition of positive ideal solution (PS) and negative ideal solution (NS) as follows:

$$
\begin{gathered}
V_{j}^{+}=\max _{i}\left(Y_{i j}^{U}\right), \text { If } J \in B ; \min _{i}\left(Y_{i j}^{L}\right) \text { If } J \in C \\
V_{j}^{-}=\min _{i}\left(Y_{i j}^{L}\right), \text { If } J \in B ; \max _{i}\left(Y_{i j}^{U}\right),
\end{gathered}
$$

where $V_{j}^{+}$and $V_{j}^{-}$denote the values of PS and NS respectively while $B$ and $C$ represent the beneficial criterion and non-beneficial criterion respectively.

Step 6. The evaluation of each alternative separation from the PS and NS respectively as follows:

$$
\begin{aligned}
& Z_{j}^{+}=\left\{\sum_{V \in B}\left(Y_{i j}^{L}-V_{j}^{+}\right)^{2}+\sum_{J \in C}\left(Y_{i j}^{U}-V_{j}^{-}\right)^{2}\right\}^{\frac{1}{2}} \\
& Z_{j}^{-}=\left\{\sum_{J \in B}\left(Y_{i j}^{L}-V_{j}^{+}\right)^{2}+\sum_{J \in C}\left(Y_{i j}^{U}-V_{j}^{-}\right)^{2}\right\}^{\frac{1}{2}}
\end{aligned}
$$

where $Z_{j}^{+}$and $Z_{j}^{-}$represent the separation of each alternative from PS and NS respectively

Step 7. The rough TOPSIS performance value of each alternative, $Z A_{\tilde{i}}$, is evaluated as follows:

$$
Z A_{i}=\frac{Z_{i}^{-}}{\left(Z_{i}^{-}+Z_{i}^{+}\right)}
$$

\section{Results and Discussion}

\subsection{Numerical Example}

The proposed Rough TOPSIS suitability in analyzing different causes of engineering systems failure is illustrated with a numerical example. In the numerical example, twoexperts assigned score to each causes of engineering system failurebased on 3 decision criteria whilst utilizing 5-point likert scale. The assigned rating which form the decision problem is shown in Table 1.The two experts also assigned rating to the three decision criteria; DC1, DC2 and DC3 in the order of importance based on 5 point likert scale, as shown in Table 2.

Table 1 - Experts assigned rating to alternatives

\begin{tabular}{|c|c|c|c|c|c|c|}
\hline \multirow{2}{*}{ S/N } & \multicolumn{3}{|c|}{ Expert 1 } & \multicolumn{3}{c|}{ Expert 2 } \\
\cline { 2 - 7 } & DC1 & DC2 & DC3 & DC1 & DC2 & DC3 \\
\hline AT1 & 5 & 4 & 5 & 4 & 3 & 5 \\
\hline AT2 & 4 & 3 & 3 & 3 & 4 & 3 \\
\hline AT3 & 4 & 3 & 2 & 2 & 3 & 2 \\
\hline AT4 & 3 & 4 & 2 & 3 & 3 & 4 \\
\hline AT5 & 2 & 2 & 1 & 1 & 4 & 1 \\
\hline
\end{tabular}

Table 2 - Ratings for decision criteria importance

\begin{tabular}{|c|c|c|c|}
\hline Expert & DC1 & DC2 & DC3 \\
\hline 1 & 4 & 2 & 5 \\
\hline 2 & 4 & 2 & 3 \\
\hline
\end{tabular}

\subsection{Rough TOPSIS Analysis}

In the Rough TOPSIS, the rough weights of the decision criteria are needed as part of the analysis process. On this basis, decision criteria are evaluated using the equations (1) - (6) and the detailed procedure on the analysiscan be found in the work of [9], and results produced are indicated in Table 3. 
Table 3 - Decision criteria rough weights

\begin{tabular}{|c|c|c|}
\hline S/N & Rough weights & $\begin{array}{c}\text { Normalized } \\
\text { rough weights }\end{array}$ \\
\hline DC1 & {$[4,4]$} & {$[0.889,0.889]$} \\
\hline DC2 & {$[2,2]$} & {$[0.444,0.444]$} \\
\hline DC3 & {$[3.5,4.5]$} & {$[0.778,1.000]$} \\
\hline
\end{tabular}

The above process is proceeded with Rough TOPSIS analysis which begins with the formation of the group rough decision matrix. To form the matrix, the individual expert ratings in Table 1 is aggregated using the equations (1) - (6) with the detailed procedure in the reference [10]. The group rough matrix developed from the analysis is indicated in Table 4.

The assigned rating for alternative, AT2 against decision criteria, DC1 (AT2 / DC1) [3-4] is applied to demonstrate the analysis:

$$
\begin{gathered}
\operatorname{Lim}(4)=\frac{3+4}{2}=3.5 \\
\operatorname{Lim}(3)=3 \\
\operatorname{Lim}(4)=4 \\
\operatorname{Lim}(3)=\frac{3+4}{2}=3.5
\end{gathered}
$$

The lower limits and upper limits values are now averaged to form rough number $R N\left(\frac{A T 2}{D C 2}\right)$ as follows:

$$
\begin{gathered}
\left(\frac{A T 2}{D C 2}\right)^{L}=\frac{3.5+3}{2}=3.25 \\
\left(\frac{A T 2}{D C 2}\right)^{U}=\frac{4+3.5}{2}=3.75 \\
R N\left(\frac{A T 2}{D C 2}\right)=[3.25,3.75]
\end{gathered}
$$

Table 4 - Group rough decision matrix

\begin{tabular}{|c|c|c|c|c|c|c|}
\hline S/N & \multicolumn{2}{|c|}{ DC1 } & \multicolumn{2}{c|}{ DC2 } & \multicolumn{2}{c|}{ DC3 } \\
\hline AT1 & 4.25 & 4.75 & 3.25 & 3.75 & 5.0 & 5.0 \\
\hline AT2 & 3.25 & 3.75 & 3.25 & 3.75 & 3.0 & 3.0 \\
\hline AT3 & 2.50 & 3.50 & 3.00 & 3.00 & 2.0 & 2.0 \\
\hline AT4 & 3.00 & 3.00 & 3.25 & 3.75 & 2.5 & 3.5 \\
\hline AT5 & 1.25 & 1.75 & 2.50 & 3.50 & 1.0 & 1.0 \\
\hline
\end{tabular}

After the formation of the group rough decision matrix, the next step is the development of the normalized form of it using the equations (9) - (10), and the generated result is shown in Table 5. The is followed with the formation of the weighted normalized matrix in Table 6 , applying the equations (11) - (12) on data in Tables 3, 5 . The values of PS and NS is then evaluated, applying the equations (13) - (14) on data in Table 6 , and the results obtained are shown in Table 7. Applying the equations (15) - (17) $Z^{+}, Z^{-}$and rough TOPSIS performance index, $\mathrm{ZA}$, are evaluated respectively and the results produced are shown in Table 8. The engineering system failure causes; AT1, AT2, AT3, AT4 and AT5 are ranked based on their respective rough performance scores. The rank orders of the alternatives are shown in Table 8 and Figure 1.

Table 5 - Normalized rough decision matrix

\begin{tabular}{|c|c|c|c|c|c|c|}
\hline S/N & \multicolumn{2}{|c|}{ DC1 } & \multicolumn{2}{c|}{ DC2 } & \multicolumn{2}{c|}{ DC3 } \\
\hline AT1 & 0.895 & 1.000 & 0.867 & 1.000 & 1.000 & 1.000 \\
\hline AT2 & 0.684 & 0.789 & 0.867 & 1.000 & 0.600 & 0.600 \\
\hline AT3 & 0.526 & 0.737 & 0.800 & 0.800 & 0.400 & 0.400 \\
\hline AT4 & 0.632 & 0.632 & 0.867 & 1.000 & 0.500 & 0.700 \\
\hline AT5 & 0.263 & 0.368 & 0.667 & 0.933 & 0.200 & 0.200 \\
\hline
\end{tabular}

Table 6 - Weighted normalized rough decision matrix

\begin{tabular}{|l|l|l|l|l|l|l|}
\hline S/N & \multicolumn{2}{|c|}{ DC1 } & \multicolumn{2}{c|}{ DC2 } & \multicolumn{2}{c|}{ DC3 } \\
\hline AT1 & 0.796 & 0.889 & 0.385 & 0.444 & 0.778 & 1.000 \\
\hline AT2 & 0.608 & 0.701 & 0.385 & 0.444 & 0.467 & 0.600 \\
\hline AT3 & 0.468 & 0.655 & 0.355 & 0.355 & 0.311 & 0.400 \\
\hline AT4 & 0.562 & 0.562 & 0.385 & 0.444 & 0.389 & 0.700 \\
\hline AT5 & 0.234 & 0.327 & 0.296 & 0.414 & 0.156 & 0.200 \\
\hline
\end{tabular}

Table 7 - Values of PS and NS

\begin{tabular}{|c|c|c|c|}
\hline Parameter & DC1 & DC2 & DC3 \\
\hline PS & 0.889 & 0.444 & 1.000 \\
\hline NS & 0.234 & 0.296 & 0.156 \\
\hline
\end{tabular}

Table 8 - Rough TOPSIS performance score $(Z A)$ and rank

\begin{tabular}{|c|c|c|c|c|c|}
\hline $\mathrm{S} / \mathrm{N}$ & $\begin{array}{c}\text { Engineering system } \\
\text { failure causes }\end{array}$ & $\mathrm{Z}^{+}$ & $\mathrm{Z}^{-}$ & $\mathrm{ZA}$ & $\mathrm{Rank}$ \\
\hline AT1 & $\begin{array}{c}\text { Ineffective mainte- } \\
\text { nance }\end{array}$ & 0.248 & 1.079 & 0.813 & 1 \\
\hline AT2 & $\begin{array}{c}\text { Misappropriation } \\
\text { of fund }\end{array}$ & 0.606 & 0.661 & 0.522 & 2 \\
\hline AT3 & Insufficient fund & 0.812 & 0.490 & 0.376 & 4 \\
\hline AT4 & $\begin{array}{c}\text { Insufficient skilled } \\
\text { manpower }\end{array}$ & 0.696 & 0.652 & 0.484 & 3 \\
\hline AT5 & Wrong location & 1.079 & 0.157 & 0.127 & 5 \\
\hline
\end{tabular}

From Table 8 and Figure 1, the most critical cause of engineering system failure in most developing countries is ineffective maintenance; AT1 having the highest value of rough TOPSIS performance score of 0.813 . The least cause of the systems failure is wrong location AT5 having the least rough TOPSIS performance score and ranked fifth position among the five alternative causes of failure.

For developing countries to improve on telecommunication, health care delivery, water transportation, power generation among others, there is the need for them to put in place, an effective maintenance scheme that will guarantee safe and reliable operation of the machinery of an engineering system. 


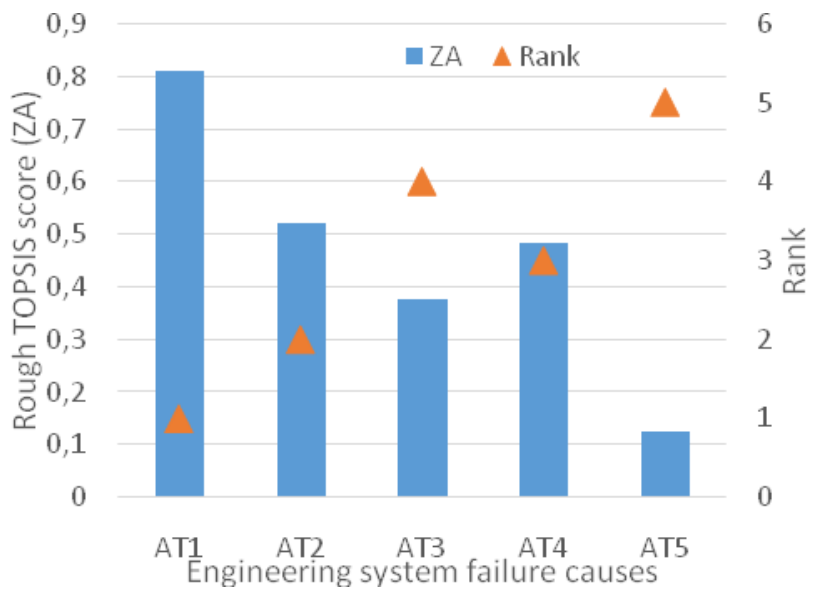

Figure 1 - Rough TOPSIS performance score $(Z A)$ and rank

\subsection{Rough TOPSIS comparison with other existing MCDM tools in literature}

Although, other multi-criteria decision making (MCDM) tools such as, PROMETHEE, AHP, ELECTRE and DEMATEL when applied as stand alone or in conjunction with other techniques can produce similar result with that of Rough TOPSIS. However, the choice of tools generally depends on the analysts' which is normally guided by appropriateness and computational effort required [11]. In the light of this, a similar technique applied by Emovon [12] in comparing different MCDM tools is utilized in this paper to compare Rough TOPSIS with other hybrid MCDM tools.

Hand calculation / spreadsheet: tick - easy to calculate using hand calculation / spreadsheet, and cross - difficult to calculate using hand calculation / spreadsheet.

Software code: tick - easy to code and cross - difficult to code.

Additional tool: Tick- no additional tool required to implement \& Cross- additional tool is required for implementation.

From Table 9, it is clearly shown that the Rough TOPSIS can be more easily analyzed and implemented than other hybrid methods due to the fact that the methodology process can be solved with either hand calculation or spreadsheet with less effort. Furthermore, from the Table, no additional tool is required, in the implementation of the tool and this is as a result of the Rough Set Theory capability of evaluating decision criteria weights and at the same time managing the uncertainty of different experts' opinions.

Table 9 - Level of computational effort required of MCDM tools

\begin{tabular}{|c|c|c|c|c|c|c|}
\hline Ppproach & $\begin{array}{c}\text { Rough } \\
\text { TOPSIS }\end{array}$ & $\begin{array}{c}\text { FUZZY- } \\
\text { AHP }\end{array}$ & $\begin{array}{c}\text { FUZZY- } \\
\text { DEMATEL }\end{array}$ & $\begin{array}{c}\text { AHP- } \\
\text { DEMATEL }\end{array}$ & $\begin{array}{c}\text { AHP- } \\
\text { ELECTRE }\end{array}$ & $\begin{array}{c}\text { AHP- } \\
\text { PROMETHEE }\end{array}$ \\
\hline Hand calculation & $\checkmark$ & $\times$ & $\times$ & $\times$ & $\times$ & $\times$ \\
\hline Spreadsheet & $\checkmark$ & $\checkmark$ & $\times$ & $\times$ & $\times$ & $\times$ \\
\hline Easy to code & $\checkmark$ & $\times$ & $\times$ & $\times$ & $\times$ & $\times$ \\
\hline Additional tool & $\checkmark$ & $\checkmark$ & $\checkmark$ & $\times$ & $\times$ & $\times$ \\
\hline
\end{tabular}

\section{Conclusion}

This paper presented a technique for analyzing engineering system failure causes. The technique utilized Rough TOPSIS which integrate Rough Set Theory and TOPSIS method for evaluating causes of engineering system failure causes. The result of the analysis indicate that ineffective maintenance is the most critical cause of engineering system failure in most developing countries.
The Rough TOPSIS approach used in the analysis is simpler in terms of implementation when comparedto other hybrid techniques, as the approach is easier to code and implement with the use of hand calculation/spreadsheet. Furthermore, the approach does not require the use of additional tools for it implementation as opposed to most other approaches which require additional tool for decision criteria weights analysis and experts information aggregation.

\section{References}

1. Ohajianya, A. C., Abumere, O. E., Owate, I. O., \& Osarolube, E. (2014). Erratic Power Supply in Nigeria: Causes and Solutions. International Journal of Engineering Science Invention, Vol. 3, No. 7, pp. 51-55.

2. Olaoye, T., Ajilore, T., Akinluwade, K., Omole, F., \& Adetunji, A. (2016). Energy crisis in Nigeria: Need for renewable energy mix. American Journal of Electrical and Electronic Engineering, Vol. 4, No. 1, pp. 1-8.

3. Sambo, A. S., Garba, B., Zarma, I. H., \& Gaji, M. M. (2012). Electricity generation and the present challenges in the Nigerian power sector. Journal of Energy and Power Engineering, Vol. 6, No. 7, pp. 1050.

4. Emovon, I., \& Nwaoha, T. (2018). Power generation problems ranking using a combination of AHP AND MOORA techniques. Research in Logistics and Production, Vol. 8, No. 2, pp. 155-168.

5. Emovon, I., \& Samuel, O. D. (2017). Prioritising alternative solutions to power generation problems using MCDM techniques: Nigeria as case study. International Journal of Integrated Engineering, Vol. 9, No. 3, pp. 11-17. 
6. Stević, Ž., Tanackov, I., Vasiljević, M., \& Rikalović, A. (2017). Supplier evaluation criteria: AHP rough approach. 27th International Scientific Conference on Industrial Systems, pp. 298-303.

7. Pawlak, Z. (1982). Rough sets. International Journal of Computer and Information Sciences, Vol. 11, No. 5, pp. 341-356.

8. Abu-Donia, H. M. (2012). Multi knowledge based rough approximations and applications. Knowledge-Based Systems, Vol. 26, pp. 20-29.

9. Song, W., Ming, X., Wu, Z., \& Zhu, B. (2014). A rough TOPSIS approach for failure mode and effects analysis in uncertain environments. Quality and Reliability Engineering International, Vol. 30, No. 4, pp. 473-486.

10. Zhai, L. Y., Khoo, L. P., \& Zhong, Z. W. (2009). A rough set based QFD approach to the management of imprecise design information in product development. Advanced Engineering Informatics, Vol. 23, No. 2, pp. 222-228.

11. Löken, E. (2007). Use of multicriteria decision analysis methods for energy planning problems. Renewable and Sustainable Energy Reviews, Vol. 11, No. 7, pp. 1584-1595.

12. Emovon, I. (2016). Multi-criteria decision making support tools for maintenance of marine machinery systems. $\mathrm{PhD}$ thesis, School of Marine Science and Technology, Newcastle University, UK.

\title{
Застосування засобів Rough TOPSIS для аналізу причин відмов інженерних систем
}

\author{
Емовон І., Нваоа Т.
}

Федеральний університет нафтових ресурсів, Р.М.В. 1221, м. Еффурун, Нігерія

Анотація. У роботі розглянута проблема визначення пріоритетів причин відмов інженерних систем. Відповідно, є потреба у розвитку інструмента для ідентифікації критичних проблем в інженерних системах для полегшення прийняття рішень при розподілі наявних ресурсів у забезпеченні оптимальної продуктивності системи. У роботі запропонована теорія грубих множин шляхом застосування засобів RoughTOPSIS для упорядкування за подібністю до досягнення ідеального рішення. Такий підхід дозволяє поєднати теорію грубих множин і TOPSIS для визначення пріоритетів у заданому інженерному середовищі. Наведені числовий приклад використання запропонованого методу та вдосконалена методика використання інформації від експертів. Як результаті дослідження, були виявлені фактори (причини), що перешкоджають оптимальному функціонуванню інженерної системи, у порядку їх значущості. Запропонований підхід має відносні переваги над іншими гібридними методами, що легко можна здійснити за допомогою ручного розрахунку або електронної таблиці, не вимагаючи додаткових інструментів для оцінювання критеріїв прийняття рішень та сукупних думок експертів.

Ключові слова: теорія грубих множин, Rough TOPSIS, інженерна система, причини відмови, критерії прийняття рішення. 